Journal of Bangladesh Academy of Sciences, Vol. 35, No. 2, 141-151, 2011

\title{
A LABORATORY BASED STUDY ON THE MOVEMENT OF RADIOCAESIUM IN SOME SOIL COLUMNS BY GAMMA SPECTROMETER
}

\author{
M.M. HAQUE, S. GHOSE ${ }^{1}$ AND S.M.A. ISLAM* \\ Department of Physics, Jahangirnagar University, Savar, Dhaka-1342, \\ Bangladesh
}

\section{ABSTRACT}

The fate and movement of ${ }^{137} \mathrm{Cs}$ in different types of soil profiles of Chittagong City and Ishwardi Upazila of Bangladesh were investigated with laboratory based column method by $\gamma$-spectrometer. The diffusion coefficient, distribution coefficient and retardation factors of ${ }^{137} \mathrm{Cs}$ were measured. The physio-chemical characteristics and radioactive concentration of natural radionuclides of the soil samples were also measured. The maximum diffusion coefficient was found $2.06 \times 10^{-5} \mathrm{~cm}^{2} / \mathrm{s}$ in the investigated soils. The vertical movement of ${ }^{137} \mathrm{Cs}$ in those soil samples found to be slow. Maximum of clay content corresponded with the maximum of retardation factor and with the minimum of diffusion coefficient. This experimental findings demonstrated that caesium is strongly absorbed in soil particles and therefore, do not pose any threat to ground water contamination by the approximated future accidental release of ${ }^{137} \mathrm{Cs}$ in the study area. Moreover, the locally available clay can be used as an adsorbent for the decontamination of liquid radioactive waste generated at nuclear facilities without any pretreatment.

Key words: Radioisotopes, Physio-chemical, Transport parameters, Soil column

\section{INTRODUCTION}

The world-wide power crisis has involved countries to re-install or to newly install of nuclear power plants. The Government of Bangladesh has a plan to implement the nuclear power plant in the country to radically meet up the power crisis in Bangladesh.

The presence of the artificial radionuclide like ${ }^{137} \mathrm{Cs}$ in the terrestrial environment may be conditioned by nuclear weapon test, nuclear accident and unauthorized releases. Chernobyl nuclear power plant accident released huge amount of ${ }^{137} \mathrm{Cs}$ radionuclide in the environment. Major part of ${ }^{137} \mathrm{Cs}$ had been accumulated in the upper soil layer (Lubyte and Antanaitis 2004). Vertical transport of ${ }^{137} \mathrm{Cs}$ is dependent on numerous factors: sorption and desorption processes, soil mineral composition, soil moisture and precipitation, particle size and specific surface area, soil type, $\mathrm{pH}$, organic matter content, cation competitive effects, etc. (Barisic et al. 1999). It is generally agreed that caesium

\footnotetext{
${ }^{1}$ Nuclear Safety \& Radiation Control Division, Bangladesh Atomic Energy Commission, Kazi Nazrul Islam Avenue, Ramna, Dhaka.

*Corresponding author: <azharphyd@yahoo.com>.
} 
migrates slowly in most of soil samples. The strong fixation to frayed edge sites and inter lattice binding sites in mineral clay soils prevent caesium from taking mobile form i.e. ionic, exchangeable or water-soluble (Arapis and Karandinos 2004).

The behavior of radionuclide transport in soil is one of the most important factors to be considered when carrying out safety analyses of radioactive waste. The interaction of radionuclide with soil has been recognized as one of the most important processes determining the migration of radionuclide in groundwater. Available literature contains limited information on the various factors affecting the transport of radiocaesium with soils. To demonstrate the environmental safety assessment for the disposal of ${ }^{137} \mathrm{Cs}$ radionuclide in a geological formation, several investigations are required to calculate the possible release of radionuclide into environment or ground water (Ohnuki 1986, Atun and Kilisliaglu 2003). ${ }^{137} \mathrm{Cs}$ is an important source of radioactivity in the waste from the nuclear facilities. It is a fission fragment decay product of uranium and plutonium originating from the fallout from nuclear weapon tests in the atmosphere during 1960 and 1970 and also from the Chernobyl nuclear power plant accident in $1986 .{ }^{137} \mathrm{Cs}$ is a very hazardous radionuclide due to its chemical behavior as well as long half life (30 years). Furthermore, because of its chemical similarity to $\mathrm{K}$, Cs is readily assimilated by terrestrial and aquatic organisms (Apak et al.1995, Bagosi Cseenji 1999 and Poinssot and Bradbury 1999). If the ${ }^{137} \mathrm{Cs}$ are released, they would migrate mainly through natural media and reach to population. Those investigations have determined the transport parameters such as diffusion coefficient $\left(\mathrm{D}_{\mathrm{s}}\right)$, distribution coefficient $\left(\mathrm{K}_{\mathrm{d}}\right)$ and retardation factor ( $\mathrm{R}$ ) of long lived radionuclide ${ }^{137} \mathrm{Cs}$ in various type of soil samples collected from Chittagong city area and Ishwardi Upazila of Bangladesh which was sequentially washed out average 172 hrs of 60 days by column method.

The aim of this study was to determine the depth concentration and transport parameters $\left(D_{s}, K_{d}\right.$ and $\left.R\right)$ of critical radionuclide ${ }^{137} \mathrm{Cs}$ in the fixed soil column with the interaction of radiocaesium in different types of soils (River soil, Low land soil, High land soil, Hilly soil, and Agriculture soil) collected from Chittagong city area and Ishwardi Upazila of Bangladesh.

\section{METHODS AND MATERIALS}

The sampling sites were selected on the agricultural area, low land area, high land area, hilly area and river area of the Chittagong city and Ishwardi Upazila of Bangladesh. Soils were collected from Jangalpara, Chandgaon Radio Station area, Panchilaish, Phartali Railway Station area, Lebubagan Hill, Batali Hill, Sadarghat River Point and Bondar River Point of Chittagong city and Char Ruppur, Pakuria, Jagonathpur, Ruppur, Joynagar, Shersha Road Side, Muladuli, Ruppur Tinbottola, Char Sahapur, Baghoil, Air Port Road Side, Dhulti, Hardinge Bridge River point, Sara Jhaudia River Point, Char 
Ruppur River Point and Lakshmikunda River Point of Ishwardi Upazila. Chittagong city soils were from a part of the Hilly soil tract and Coastal saline tract. Lower hills were mainly underlain by little-consolidated sands and shales of the Dupi Tila formation, which might be from late-Miocence age (Brammer 1996). The soils were yellow to strong brown and slightly to strongly acidic. The soils were mentioned as piedmont plains near the hills, floodplains alongside the rivers and saline tidal floodplains along the lower courses of the rivers. Ishwardi soils were from a part of the Gangetic alluvium tract which was situated on the eastern banks of the river Padma (or Ganges). This tract represented the riverine lands of the Gangetic flood plains. The soils were mentioned as calereous dark grey and brown flood plain soils.

Sample collection and preparation: Soil samples of five different categories were collected from $0-50 \mathrm{~cm}$ depth of the soil surface for the investigation. About $3000 \mathrm{gm}$ of each soil samples were collected. The collected samples were air dried and cleaned to remove the grass roots, biological matters, stones and gravels. Each sample was crushed to fine powder with agate mortar and pastel and sieved with sieve sacker (90 - $400 \mu \mathrm{m})$. Those samples were transferred into the plastic container of same geometry and sealed tightly with cap and wrapped with thick vinyl tape around their necks, marked individually with identification number, sample location, date of preparation and net weight. The samples were kept for one month to reach secular equilibrium between the ${ }^{238} \mathrm{U}$ and ${ }^{232} \mathrm{Th}$ series radionuclide with their respective progenies.

Column preparation and operation: For investigating the movement of ${ }^{137} \mathrm{Cs}$ in soil column layer a transparent PVC column of length $55 \mathrm{~cm}$ and diameter $5.34 \mathrm{~cm}$ was taken, which had been marked horizontally by drawing lines at $5 \mathrm{~cm}$ intervals by a marker pen. For safely pull up the whole soil column from the PVC column, a polythene packet of same diameter and little higher of length were inserted in the PVC columns. The polythene packet was also marked by drawing horizontal lines at $5 \mathrm{~cm}$ intervals. Total eight columns were prepared for the experiments. The columns were then randomly placed in a controlled environment room under the same conditions of light, temperature and humidity.

Processed soil from the Chittagong city area and Ishwardi Upazila had been poured into the column to make $50 \mathrm{~cm}$ depth of soil layer (weight, $\mathrm{pH}$ and bulk density of soil were recorded). The radioactive ${ }^{137} \mathrm{Cs}$ aqueous solution was used for this study. Total $4000 \mathrm{ml}$ distilled water was introduced into every soil column. At first $1000 \mathrm{ml}$ distilled water was passed during 1 - 3 days and then $3000 \mathrm{ml}$ distilled water (1000 ml each time) was passed through the soil column taking 7, 15 and 30 days intervals (passing time, release time and release amount of water with time were recorded). Same procedure was used for other soil column. After leaching had been stopped, contaminated soil column from each PVC column was opened out with polythene packet and sectioned ten parts of 
each column for radioactive concentration measurement (after dried and crushed). The radioactivity concentration of the dried and crushed soil layer and effluents were measured by a $\gamma$-ray spectrometer.

Analytical procedures: The concentrations of background radionuclide $\left({ }^{226} \mathrm{Ra},{ }^{232} \mathrm{Th}\right.$ and ${ }^{40} \mathrm{~K}$ ) and ${ }^{137} \mathrm{Cs}$ contaminated in selected soil for migration study were determined in $150 \mathrm{ml}$ cylindrical geometry beakers using a high purity germanium (HPGe) detector, having a relative efficiency of $40 \%$ and FWHM $1.8 \mathrm{keV}$ at $1332 \mathrm{keV}$ gamma energy of ${ }^{60} \mathrm{Co}$. The detector was calibrated with standard solutions of known energy. The counting efficiency calibration was done by $150 \mathrm{ml}$ cylindrical geometry with ${ }^{152} \mathrm{Eu}$ standard solution. Spectra were analyzed by Multi-channel Analyzer (MCA) and using Geniee 2000 software from Canberra. In the present study, all observation were taken in the laboratory of AERE, Savar, Dhaka. The activity concentrations of ${ }^{232} \mathrm{Th}$ and ${ }^{226} \mathrm{Ra}$ were calculated assuming secular equilibrium with their decay products (Kabir et al. 2009).

Vertical diffusion coefficient $\left(D_{x}\right)$ : The investigation of radionuclide transport in porous media like soil had shown that there were many situations where molecular diffusion was the dominant migration mechanism. In those situations the transport characteristics could be described by the diffusion coefficient of the radionuclide in the medium. The vertical diffusion coefficients of ${ }^{137} \mathrm{Cs}$ in the soil column layer were calculated by the following equations (Liu et al. 2003):

$$
D x=\frac{1}{2} \cdot \frac{d \sigma_{x}^{2}}{d t} \approx \frac{1}{2} \cdot \frac{\sigma_{x}^{2}}{t}
$$

where, $D_{x}$ is the vertical diffusion coefficient, in $\mathrm{cm}^{2} / \mathrm{d}, \mathrm{t}$ is the time spent, in seconds, and $\sigma_{x}^{2}$ is the squared difference of the vertical concentration distribution, in $\mathrm{cm}^{2}$, $\sigma^{2}$ was determined by the following equations:

$$
\sigma_{x}^{2}(t)=\frac{\int c(x-x 0)^{2} d x}{\int C d x} \approx \frac{\sum C_{i}\left(x-x_{0}\right)^{2} \Delta x_{i}}{\sum C_{i} \cdot \Delta x_{i}}
$$

where, $\mathrm{C}_{\mathrm{i}}$ is the concentration of ${ }^{137} \mathrm{Cs}$ in the soil, in $\mathrm{Bq} / \mathrm{g}, \mathrm{x}-\mathrm{x}_{0}$ is the distance from the sample position to the source layer, in $\mathrm{cm}$, and $\Delta \mathrm{x}_{\mathrm{i}}=\mathrm{x}_{\mathrm{i}}-\mathrm{x}_{\mathrm{i}-1}, \mathrm{~cm}$.

Distribution coefficient $\left(K_{d}\right)$ and Retardation factor $(R)$ : The radionuclides transport through various type of soil layer is a function of several factors, an important role being played by sorption and retardation. The distribution coefficient $\left(K_{d}\right.$ value $)$ is one of the simplest constructs that describes contaminant sorption to soil. The distribution coefficient is the ratio between the mass concentration of radionuclide on the solid phase and the concentration in the liquid phase, at the equilibrium. The equation distribution coefficients were calculated by the following equations (Bucur et al. 2000): 


$$
K_{d}=\left(\frac{A_{0}-A}{A}\right) \cdot \frac{V}{m}
$$

where, $\mathrm{K}_{\mathrm{d}}$ is the distribution coefficient in $\mathrm{ml} / \mathrm{g}, \mathrm{A}_{0}$ initial radioactivity concentration of contaminant in $\mathrm{Bq} / \mathrm{l}$ and $\mathrm{A}$ final radioactivity concentration of contaminant in $\mathrm{Bq} / \mathrm{l}$. Retardatation factors were calculated by the following equations (Bucur et al. 2000):

$$
R=1+\frac{K d \rho}{\eta}
$$

where, $\mathrm{R}$ is the retardate factor, $\mathrm{r}$ soil density in $\mathrm{g} / \mathrm{cm}^{3}, \mathrm{~h}$ porosity of the soil in $\mathrm{cm}^{3} / \mathrm{cm}^{3}$ and $\mathrm{K}_{\mathrm{d}}$ distribution coefficient in $\mathrm{ml} / \mathrm{g}$.

\section{RESULTS AND DISCUSSION}

Physio-chemical characteristics of the soil sample : Table 1 presents the data of physio-chemical characteristics of the soil samples. The porosity and bulk density of different types of soil were calculated using the following formulas:

$$
\begin{aligned}
& \text { Soil porosity }=\frac{\text { Wet weight }(\mathrm{g})-\text { dry weight }(\mathrm{g})}{\text { Soil volume }\left(\mathrm{cm}^{3}\right)} \times 100 \% \\
& \text { Bulk density }=\frac{\text { Weight dry soil }(\mathrm{g})}{\text { Volume dry soil }\left(\mathrm{cm}^{3}\right)}
\end{aligned}
$$

Table 1. Physio-chemical characteristics of the soil samples.

\begin{tabular}{lllllllll}
\hline Sampling site & \multicolumn{4}{c}{ Chittagong City } & \multicolumn{5}{c}{ Ishwardi Upazila } \\
\hline${ }^{1}$ Soil type & AS & LLS & HS & RS & AS & LLS & HLS & RS \\
${ }^{2}$ Soil texture & SiL & C & SiCL & SL & L & C & CL & LS \\
pH (distiled water) & 5.8 & 5.2 & 5.6 & 6.0 & 8.6 & 8.1 & 8.3 & 8.5 \\
Bulk Density (gm/cc) & 1.38 & 1.24 & 1.28 & 1.47 & 1.45 & 1.15 & 1.29 & 1.58 \\
Porosity (\%) & 45 & 53 & 51 & 42 & 46 & 57 & 49 & 39 \\
*Clay (\%) & $11-15$ & $45-40$ & $34-30$ & $10-19$ & $15-20$ & $75-80$ & $36-27$ & $4-8$ \\
*Silt (\%) & $57-60$ & $40-54$ & $60-50$ & $22-29$ & $35-40$ & $20-10$ & $35-42$ & $21-10$ \\
*Sand $(\%)$ & $27-28$ & $15-06$ & $06-20$ & $68-52$ & $50-40$ & $5-10$ & $29-31$ & $75-82$ \\
Org. matter $(\%)$ & 2.13 & 3.04 & 2.03 & 1.26 & 2.62 & 2.33 & 2.25 & 0.93 \\
K (mle/100g) & 0.11 & 0.24 & 0.14 & 0.16 & 0.3 & 0.11 & 0.18 & 0.25 \\
Ca (mle/100g) & 3.92 & 2.76 & 4.73 & 5.12 & 14.4 & 14.5 & 12.05 & 14.6 \\
Mg (mle/100g ) & 2.58 & 1.38 & 2.84 & 2.81 & 1.4 & 1.3 & 1.73 & 1.8 \\
$($ Ca+Mg)/K & 59.09 & 17.25 & 54.07 & 49.56 & 52.66 & 143.63 & 75.41 & 65.6 \\
\hline
\end{tabular}

${ }^{1}$ AS: Agriculture soil, LLS: Low land soil, HS: Hilly soil, RS: River soil, HLS: High land soil, ${ }^{2}$ SiL: Silt loam. C: Clay, SiCL: Silty clay loam, SL: Sandy loam, L: loam, CL: Clay loam, LS: Loamy sand.

*Data reported in the table collected from published literature (Rahman 2005, Brammer 1996). 
Radioactive concentration of natural radionuclide in the investigated soil : The radioactive concentration of natural radionuclide in the soil samples were measured by using the HPGe gamma spectrometry of $40 \%$ relative efficiency. The results are shown in Tables 2 and 3. The average concentration of ${ }^{226} \mathrm{Ra},{ }^{232} \mathrm{Th}$ and ${ }^{40} \mathrm{~K}$ in the Chittagong soil samples obtained were $33.72 \pm 4.05,58.14 \pm 5.81$ and $582.35 \pm 69.88 \mathrm{~Bq} / \mathrm{kg}$, respectively and in Ishwardi soil samples obtained were $47.25 \pm 4.64 \mathrm{~Bq} / \mathrm{kg}^{-1}, 49.28 \pm 4.39$ and $637.69 \pm 59.19 \mathrm{~Bq} / \mathrm{kg}$, respectively. However, in tho se soils, no activity of ${ }^{137} \mathrm{Cs}$ had been detected.

Table 2. Concentration of natural radionuclide in the Chittagong soil samples.

\begin{tabular}{lccccc}
\hline \multirow{2}{*}{ Type of soil } & Sample & \multicolumn{4}{c}{ Activity concentration $(\mathrm{Bq} / \mathrm{Kg})$} \\
\cline { 3 - 6 } & No. & ${ }^{137} \mathrm{Cs}$ & ${ }^{40} \mathrm{~K}$ & ${ }^{226} \mathrm{Ra}$ & ${ }^{232} \mathrm{Th}$ \\
\hline \multirow{3}{*}{ Agriculture soil } & CAS1 & ND & $763.55 \pm 83.99$ & $33.01 \pm 3.99$ & $58.90 \pm 5.89$ \\
& CAS2 & ND & $\mathbf{8 0 4 . 1 7} \pm \mathbf{9 6 . 5 0}$ & $27.51 \pm 3.03$ & $64.84 \pm 5.83$ \\
& CAS3 & ND & $732.81 \pm 87.93$ & $\mathbf{4 7 . 9 2} \pm \mathbf{5 . 7 5}$ & $54.62 \pm 5.46$ \\
& CAS4 & ND & $667.99 \pm 73.47$ & $37.52 \pm 4.50$ & $67.34 \pm 6.73$ \\
Low land soil & CLLS1 & ND & $407.52 \pm 48.90$ & $32.16 \pm 3.86$ & $39.07 \pm 3.90$ \\
& CLLS2 & ND & $536.74 \pm 64.41$ & $40.52 \pm 4.86$ & $48.66 \pm 4.38$ \\
& CLLS3 & ND & $\mathbf{3 8 6 . 0 0 \pm 4 2 . 4 6}$ & $24.45 \pm 2.69$ & $59.44 \pm 5.94$ \\
Hilly soil & CLLS4 & ND & $488.67 \pm 58.64$ & $30.01 \pm 3.60$ & $54.37 \pm 5.43$ \\
& CHS1 & ND & $593.03 \pm 56.23$ & $34.06 \pm 4.09$ & $\mathbf{9 3 . 5 1 \pm 8 . 4 1}$ \\
& CHS2 & ND & $612.33 \pm 73.48$ & $34.11 \pm 4.09$ & $61.73 \pm 6.17$ \\
& CHS3 & ND & $688.24 \pm 82.59$ & $\mathbf{2 3 . 1 4} \pm \mathbf{2 . 7 8}$ & $81.95 \pm 8.19$ \\
River soil & CHS4 & ND & $511.19 \pm 61.34$ & $46.31 \pm 5.09$ & $\mathbf{3 7 . 4 3 \pm 3 . 3 7}$ \\
& CRS1 & ND & $492.64 \pm 54.19$ & $26.09 \pm 3.13$ & $45.81 \pm 4.58$ \\
Average & CRS2 & ND & $603.88 \pm 72.46$ & $26.73 \pm 3.21$ & $46.75 \pm 4.20$ \\
& CRS3 & ND & $418.17 \pm 50.18$ & $36.68 \pm 4.40$ & $70.24 \pm 7.02$ \\
& CRS4 & ND & $610.68 \pm 73.28$ & $39.21 \pm 4.31$ & $45.52 \pm 4.55$ \\
& & - & $\mathbf{5 8 2 . 3 5 \pm 6 9 . 8 8}$ & $\mathbf{3 3 . 7 2 \pm 4 . 0 5}$ & $\mathbf{5 8 . 1 4 \pm 5 . 8 1}$ \\
\hline
\end{tabular}

Table 3. Concentration of natural radionuclide in the Ishwardi soil samples.

\begin{tabular}{lccccc}
\hline \multirow{2}{*}{ Type of soil } & Sample & \multicolumn{4}{c}{ Activity concentration $(\mathrm{Bq} / \mathrm{Kg})$} \\
\cline { 3 - 6 } & No. & ${ }^{137} \mathrm{Cs}$ & ${ }^{40} \mathrm{~K}$ & ${ }^{226} \mathrm{Ra}$ & ${ }^{232} \mathrm{Th}$ \\
\hline \multirow{3}{*}{ Agriculture soil } & IUAS1 & ND & $686.35 \pm 72.46$ & $46.32 \pm 4.52$ & $57.28 \pm 5.62$ \\
& IUAS2 & ND & $602.46 \pm 64.38$ & $48.35 \pm 5.69$ & $43.47 \pm 5.40$ \\
& IUAS3 & ND & $532.25 \pm 46.36$ & $\mathbf{5 2 . 2 3} \pm \mathbf{3 . 4 6}$ & $45.73 \pm 4.89$ \\
& IUAS4 & ND & $638.45 \pm 56.38$ & $37.23 \pm 4.69$ & $43.66 \pm 3.59$ \\
\hline
\end{tabular}

(Contd.) 


\begin{tabular}{lccccc}
\hline \multirow{4}{*}{ Low land soil } & IULS1 & ND & $659.74 \pm 63.15$ & $41.34 \pm 4.17$ & $\mathbf{4 2 . 2 9} \pm \mathbf{3 . 8 1}$ \\
& IULS2 & ND & $576.35 \pm 46.34$ & $32.48 \pm 3.21$ & $53.52 \pm 3.37$ \\
& IULS3 & ND & $601.49 \pm 67.29$ & $51.35 \pm 4.54$ & $53.29 \pm 5.15$ \\
& IULS4 & ND & $656.46 \pm 60.74$ & $33.58 \pm 3.76$ & $44.74 \pm 3.47$ \\
High land soil & IUHLS1 & ND & $\mathbf{7 1 8 . 5 3} \pm \mathbf{8 6 . 5 1}$ & $32.16 \pm 3.45$ & $\mathbf{6 1 . 2 8} \pm \mathbf{6 . 5 3}$ \\
& IUHLS2 & ND & $674.54 \pm 63.43$ & $34.47 \pm 3.84$ & $57.48 \pm 3.92$ \\
& IUHLS3 & ND & $547.83 \pm 48.51$ & $42.29 \pm 3.81$ & $45.60 \pm 3.82$ \\
\multirow{3}{*}{ River soil } & IUHLS4 & ND & $655.81 \pm 61.52$ & $41.23 \pm 3.93$ & $56.47 \pm 5.75$ \\
& IURS1 & ND & $687.24 \pm 59.23$ & $\mathbf{2 8 . 6 7} \pm \mathbf{3 . 4 3}$ & $45.09 \pm 3.18$ \\
& IURS2 & ND & $621.44 \pm 64.14$ & $33.84 \pm 3.12$ & $51.44 \pm 4.36$ \\
& IURS3 & ND & $\mathbf{4 9 5 . 4 5} \pm \mathbf{3 9 . 3 7}$ & $40.74 \pm 3.17$ & $57.18 \pm 3.58$ \\
& IURS4 & ND & $588.62 \pm 48.89$ & $40.84 \pm 3.92$ & $48.36 \pm 3.47$ \\
\hline
\end{tabular}

$\mathrm{ND}=$ Not detected. The maximum, minimum and average values are given in bold face.

Vertical diffusion coefficients of ${ }^{137}$ Cs: Radionuclides dissolved in groundwater were transported through vertical soil column with important mechanisms of diffusion. It moved in the direction of the higher concentration to lower concentration. (Bucur et al. 2006). Diffusion in porous soil was affected in different ways by the geometry of porous structure and by the radionuclide interaction with the pore walls. Based on the vertical distribution of ${ }^{137} \mathrm{Cs}$ in the soil column layer, the vertical diffusion coefficients of ${ }^{137} \mathrm{Cs}$

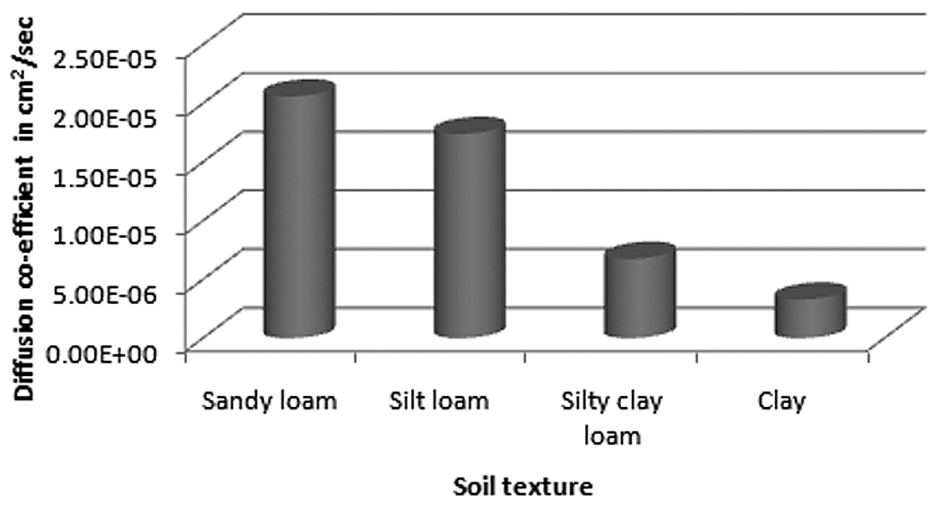

Fig. 1. Vertical diffusion coefficients of ${ }^{137} \mathrm{Cs}$ with different type of Chittagong soil.

in the silt loam, clay, silty clay loam and sandy loam textured soils of Chittagong City were calculated and the values were $1.74 \times 10^{-5}, 3.29 \times 10^{-6}, 6.76 \times 10^{-6}$ and $2.06 \times 10^{-5}$ $\mathrm{cm}^{2} / \mathrm{s}$, respectively (Fig. 1) and $1.65 \times 10^{-5}, 1.48 \times 10^{-5}, 6.02 \times 10^{-6}$ and $3.11 \times 10^{-6} \mathrm{~cm}^{2} / \mathrm{s}$ in the loamy sand, loam, clay loam and clay textured Ishwardi soils, respectively (Fig. 2). In this investigation, the diffusion coefficient in clay type low land soil was found lower than that of other soil. So, vertical movement of ${ }^{137} \mathrm{Cs}$ in clay type soil layer was slow 
compare to other soils. It was known from the literature that soil with low or moderate organic matter content and sufficient clay mineral content had strong ability of caesium fixation (Valcke and Cremers 1994). According to earlier studies (Sawhney 1970) caesium fixation is enhanced in the soils that have high clay content. The present investigation agrees with the finding of earlier studies. The adsorption of ${ }^{137} \mathrm{Cs}$ is mainly chemical and occurs through an ion exchange process (Staunton and Dumat 2002). The cation exchange capacity of clay minerals depends partly on $\mathrm{pH}$ (Eriksson et al. 2005). Increasing $\mathrm{pH}$ will therefore slightly increase the number of exchange sites. When organic matter is higher, clay minerals are not sufficient, and also migration depth of caesium is higher (Dumat and Staunton 1999, Rosén et al. 2006). This was so in the present study.

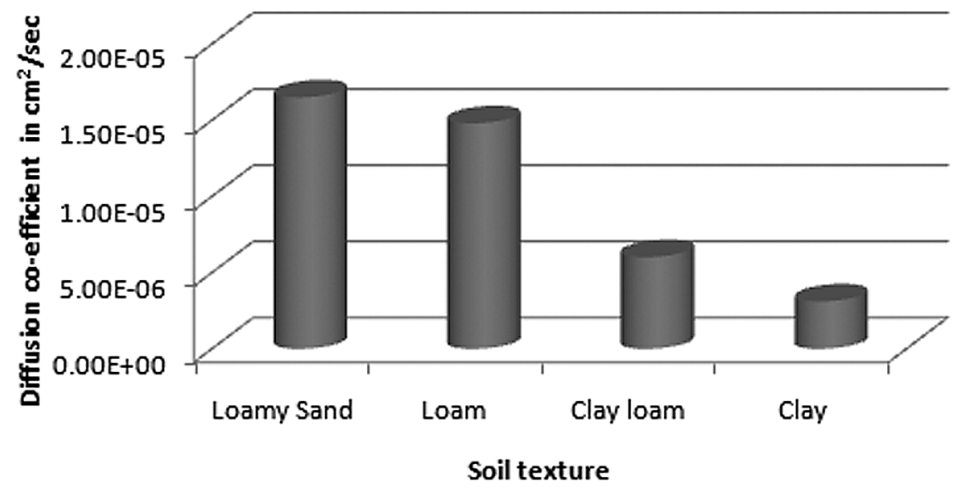

Fig. 2. Vertical diffusion coefficients of ${ }^{137} \mathrm{Cs}$ with different type of Ishwardi soil.

Distribution coefficients and retardation factors: Distribution coefficients $\left(\mathrm{K}_{\mathrm{d}}\right)$ were measured for ${ }^{137} \mathrm{Cs}$ using laboratory technique "in batch". The filtrate sample was analyzed for ${ }^{137} \mathrm{Cs}$ by gamma spectrometry. The distribution coefficients in the silt loam, clay, silty clay loam and sandy loam textured of Chittagong soil samples were calculated and found to be 58.75, 369.67, 126.62 and $31.99 \mathrm{~Bq} / 1$, respectively and retardation factors were calculated as 181.18, 865.92, 318.80 and 112.98, respectively (Fig. 3) and the distribution coefficients in the loam, clay, clay loam and loamy sand textured Ishwardi soils were found to be $62.47,380.41,142.43$ and $30.24 \mathrm{~Bq} / 1$, respectively and retardation factors were calculated as 197.90, 768.49, 375.97 and 123.52, respectively (Fig. 4). The height values of distribution coefficient and retardation factors for ${ }^{137} \mathrm{Cs}$ had been obtained for low land soil. It was a good behavior of clay content in the sorption process of radiocaesium. Clay can play the roll of natural barrier in the radionuclide migration (Bucur et al. 2000). Clay has specific site in there structure that strongly fixed the Cs ions. Caesium has low hydration energy and, if present at the site, it will lose the hydration shell and bind to the negatively charged mineral platelets, resulting in a closing 
of the site thus fixating the ion (Cornell 1993). The present investigation confirms this finding. Overall, clay particles had a very large surface area relative to their volume and comparing other types of soil i.e. sand, silt etc. This large surface was highly reactive, had the ability to attract and hold positively charged ions. Clay particles were also somewhat flexible and plastic because of their lattice-like design. This feature allowed clay particles to retardate ${ }^{137} \mathrm{Cs}$ into their structure.

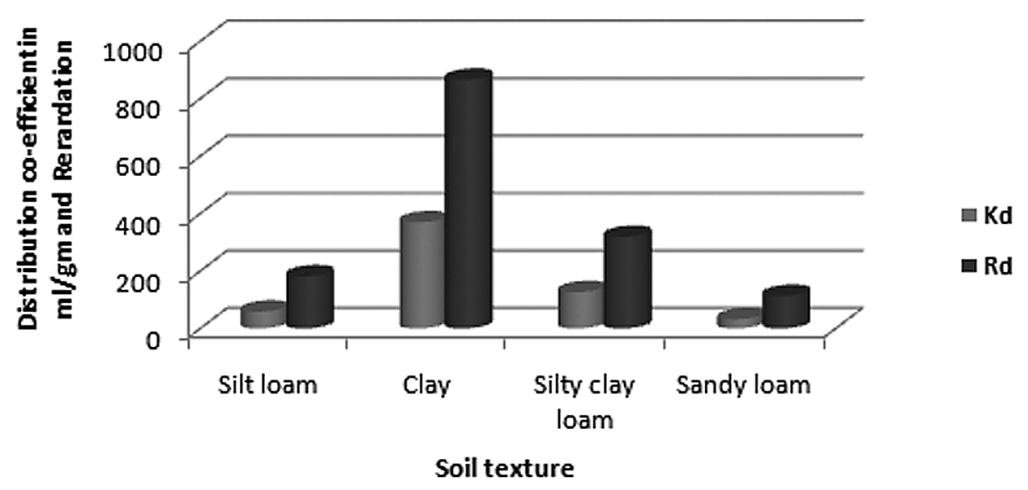

Fig. 3. Distribution coefficients and retardation factors with different type of Chittagong soil.

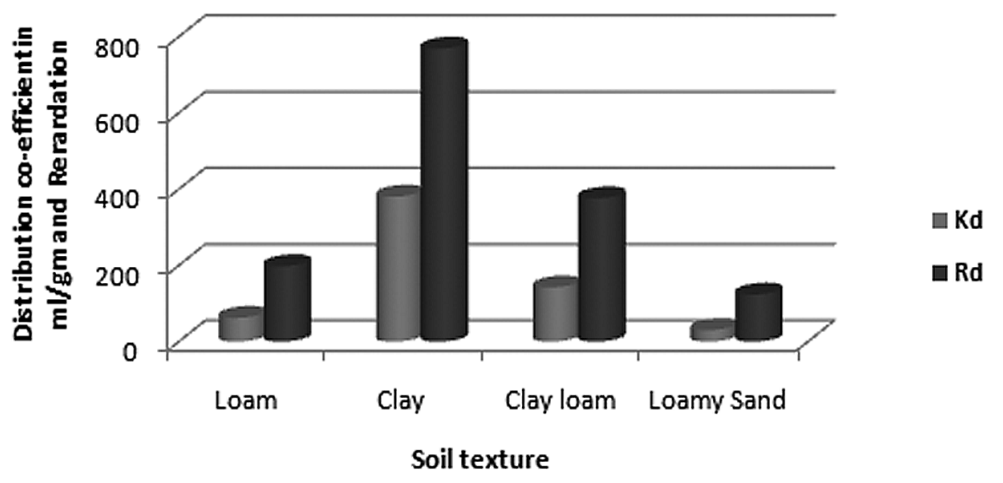

Fig. 4. Distribution coefficients and retardation factors with different type of Ishwardi soil.

\section{CONCLUSION}

The results obtained in this study shown that there was no contribution of ${ }^{137} \mathrm{Cs}$ fallout to natural deposition in the soil of study area. Some correlations were found between the transport parameters and certain physio-chemical characteristics of the soil. The vertical transport of ${ }^{137} \mathrm{Cs}$ in soil columns was slow. This finding suggests that caesium is strongly absorbed on soil particles and therefore, does not pose any threat to ground water contamination by the approximated future accidental release of ${ }^{137} \mathrm{Cs}$ in the 
study area. The investigated results show that maximum of clay content correspond with the maximum of retardation factor and with the minimum of diffusion coefficient. It was a good behavior of clay content in the sorption process of radiocaesium, consequently the clay played a role of natural barrier in the radiocaesium migration. So, locally available clay may be used as an adsorbent for the decontamination of liquid radioactive waste generated at nuclear facilities without any pretreatment. Moreover, the investigated data presented in several tables and text can be used as a base line data for future study and for any radiation protection measures taken by the Govt. of Bangladesh as and when needed.

\section{ACKNOWLEDGEMENTS}

Authors are grateful to Dr. M. M. Islam, PSO of the Health Physics and Radioactive Waste Management Unit (HP and RWMU) for his assistance and useful discussions. Authors are also grateful to the Director, INST, BAEC, Savar, for giving permission to work at the Health Physics and Radioactive Waste Management Unit (HP and RWMU), AERE, Savar.

\section{REFERENCES}

Apak, R., G. Atun and K.GiiclU.1995. Removal of ${ }^{137} \mathrm{Cs}$ and ${ }^{90} \mathrm{Sr}$ from water by unconventional sorbents (usage of red mud). J. Nucl. Sci. Tech. 32(10): 1008-1017.

Arapis, G.D. and M.G. Karandinos. 2004. Migration of ${ }^{137} \mathrm{Cs}$ in the soil of sloping semi-natural ecosystems in Northern Greece. J. Environ. Radioactivity 77: 133-142.

Atun, G. and K. Kilislioglu. 2003. Adsorption behavior of cesium on montmorillonite-type clay in the presence of potassium ions. Journal of Radio-analytical and Nuclear Chemistry 258(3): 605-611.

Bagosi, S. and L. J. Cseenyi. 1999. Immobilization of caesium loaded ion exchange resins in zeolite-cement blends. Cement Concrete Res. 29: 479-485.

Barisic, D., A. Vertacnik, and S. Lulic. 1999. Cesium contamination and vertical distribution inundisturbed soils in Croatia. J. Environ. Radioactivity 46: 361-374.

Brammer, H. 1996. The Geography of the soil of Bangladesh. University Press Limited, Red Crescent Building, 114 Motijheel C/A, Dhaka-1000, Bangladesh, pp. 204-245

Bucur, C, A. Popa, C. Arsene and M. Olteanu. 2000. Diffusion Coefficients of Critical Radionuclides from Radioactive Waste in Geological Medium. Proceedings of the WM'00 Conference, February 27 - March 2, Tucson, AZ.

Bucur, C., M. Olteanu and M. Pavelescu. 2006. Radionuclide diffusion in geological media. Rom. Jour. Phys. 51(3-4): 469-478.

Cornell, R. M. 1993. Adsorption of cesium on minerals: A review. Journal of Radio-analytical and Nuclear Chemistry 171: 483-500.

Dumat, C. and S. Staunton. 1999. Reduced adsorption of cesium on clay minerals caused by various humic substances. Journal of Environmental Radioactivity 46: 187-200.

Eriksson, J., I. Nilsson and M. Simonsson. 2005. Wiklanders Marklära. Studentlitteratur. Lund. p. 67. 
Kabir, K. A., S. M. A. Islam and M. M. Rahman. 2009. Distribution of radionuclides in surface soil and bottom sediment in the district of Jessore, Bangladesh and evaluation of radiation hazard. J. Bangladesh Acad. Sci. 33(1): 117-130.

Liu, C. L., S. S. Li, X. W. Wang, Z. M. Wang, H. F. Wang, R. J. Li, C. T. Xin, B. Li, L. Jiang and C. Z. Jia. 2003. Migration of 99Tc in unsaturated Chinese loess under natural rainfall conditions: An in-situ test. J. of Radio-analytical and Nuclear Chemistry 258(2): 411-413.

Lubyte, J. and A. Antanaitis. 2004. Migration of radionuclide in arable land of Lithuania. Journal of Environ-mental Engineering and Landscape Management, Vilnius: Technika, 12(1): 2229.

Ohnuki, T. 1986. Migration of radionuclide ${ }^{137} \mathrm{Cs}$ in alkaline solution through sandy soil layer. Journal of Nuclear Science and Technology 23(7): 643-649.

Poinssot, C. B. and M. H. Bradbury.1999. Experimental and modeling studies of caesium sorption on illite. Gcochim. Cosmochim. Acta 63(19/20) : 3217-3227.

Rahman, M. R. 2005. Soil of Bangladesh. Darpon Publications, Banglabazar, Dhaka-1100, Bangladesh. pp.187-259.

Rosén, K., C. A. Shand, E. Haak and M.V. Cheshire. 2006. Effects of clay content and wettingand-drying on radiocaesium behavior in a peat and a peaty podzol. Sci. Total Environ. 182: $117-133$

Sawhney, B.L. 1970. Potassium and caesium ion selectivity in relation to clay mineral structure. Clays and Clay Minerals 18: 47-52.

Staunton, S. and C. Dumat. 2002. Possible role of organic matter in radiocaesium adsorption in soils. J. Environ. Radioactivity 58: 163-173.

Valcke, E. and A. Cremers. 1994. Sorption-desorption dynamics of radiocaesium in organic matter soils. The Sci. of the Total Environ. 157: 275-283.

(Received revised manuscript on 20 April, 2011) 